\title{
PENGARUH DUKUNGAN ORGANISASIONAL TERHADAP KEPUASAN KERJA DAN MOTIVASI KERJA ANGGOTA UNIDADE PATRULHAMENTU FRONTEIRA (UPF) DI PERBATASAN MOTA'AIN - BATUGADE TIMOR LESTE
}

\author{
Armando Dos Santos Martins \\ Desak Ketut Sintaasih
}

Fakultas Ekonomi Dan Bisnis Universitas Udayana, Bali,Indonesia

Email: amartins74.tl@gmail.com / Phone; +670 77044793

\begin{abstract}
Effect of Organizational Support on Job Satisfaction and Work Motivation of Patrulhamentu Fronteira (UPF) Unidade Members on the Border of Mota'ain - Batugade Timor Leste. This research was conducted to examine the effect of organizational support against the job satisfaction and work motivation against the members of Border Patrol Unit. The populations were 327. However the researcher defined to have a 60 members of the unit as a sample which only focus on the ranks of Ajente, Ajente Prinsipál, Ajente Xefe and First Sergeants. This research were uses a quantitative and quantitative approach and desriptif methods against the items were be tested and described by using the average value and the percentage score by using the Smart Partial Least Square (PLS) approach.The Results of this research was shown that, the Organization Support against the job satisfaction and work motivation as well as the job satisfatin against the work motivatin of members were positive and significant effected on member's work motivation.
\end{abstract}

Keywords: Organizational Support, Job Satisfation and Work Motivation

\begin{abstract}
Abstrak: Pengaruh Dukungan Organisasional Terhadap Kepuasan Kerja dan Motivasi Kerja Anggota Unidade Patrulhamentu Fronteira (UPF) di Perbatasan Mota'ain - Batugade Timor Leste. Penelitian ini dilakukan untuk menguji pengaruh dukungan organisasional terhadap kepuasan kerja dan motivasi kerja anggota Unidade Patrulhamentu Fronteira. Populasi dalam penelitian ini berjumlah 327 orang anggota. Sampel penelitian yang ditetapkan adalah sebanyak 60 orang yang hanya di ambil berdasarkan kepangkatan Ajente, Ajente Prinsipal, Ajente Xefedan Primeiru Serjentu. Penelitian ini menggunakan pendekatan kuantitatif dan kualitatif data yang diperoleh melalui kuesioner dengan mengunakan metode analisis deskriptif terhadap item-item pertanyaan pada kuesioner. Pada teknik analisis ini seluruh variabel yang diteliti dideskripsikan dengan menggunakan nilai rata-rata dan persentase di dalam menguji hipotesis dengan menggunakan pendekatan Partial Least Square (SmartPLS). Hasil dari penelitian ini menunjukan bahwa Dukungan Organisasi berpengaruh positif dan signifikan terhadap Kepuasan Kerja Anggota dan Motivasi Kerja anggota serta Kepuasan Kerja berpengaruh positif dan signifikan terhadap Motivasi Kerja Anggota.
\end{abstract}

Kata kunci: Dukungan Organisasional, Kepuasan Kerja, Motivasi Kerja anggota Organisasi. 


\section{PENDAHULUAN \\ Latar Belakang}

Perbatasan Mota'ain - Batugade merupakan pintu keluar-masuk yang secara hukum di akui sebagai jalur resmi bagi orang dan barang yang memiliki dengan kelengkapan dokumen-dokumen sesuai dengan hukum bea-cukai dan imigrasi dari dan ke Timor Leste, tetapi kenyataan yang terjadi selama ini adalah sangat maraknya dengan aktifitasaktifitas seperti Illegal Business dan Illegal Crossing di sepanjang perbatasan hal ini di picu oleh garis perbatasan darat yang panjang dan kurangya sumber daya manusia dalam hal ini adalah anggta Unidade Patrulhamentu Fronteira - (UPF) yang merupakan tenaga profesinal di dalam penanganannya terhadap wilayah perbatasan yang pada hakekatnya merupakan bagian dari upaya perwujudan ruang wilayah nusantara "Satu Kesatuan Geografi, Politik, Ekonomi, Sosial Budaya dan Pertahanan Keamanan di sepanjang perbatasan darat Mota'ain - Batugade yang juga merupakan wilayah tertinggal, terisolasi dari pusat pertumbuhan yang mengandung banyak celah-celah kerawanan yang mengakibatkan terjadinya Illegal Crossing dan Illegal Business di sepanjang perbatasan negara Timor Leste dan Republik Indonesia yang kemungkinan besar ke depannya akan berdampak terhadap kedaulatan bangsa dan negara apabila tidak di perhatikan secara dini oleh pemerintah terhadap institusi yang berwewenang dalam hal ini adalah Polisi Nasional Timor Leste melalui Unidade Patrulhamentu Fronteira - (UPF).

Secara undang-undang ada pemisahan mandat serta keputusan politik yang jelas dan hati-hati dibuat untuk menempatkan pengawasan perbatasan di bawah bantuan eksklusif melalui Polisi Nasional Timor Leste melalui Unidade Patrulhamentu Fronteira untuk memastikan hubungan yang tidak akan adanya ancaman antara kedua Negara NKRI dan TL. Mengingat bahwa Kehidupan masyarakat Timor Leste yang bercirikan Demokrasi dan Supremasi Hukum, maka anggota Unidade Patrulhamentu Fronteira harus mampu memberikan jaminan keamanan, ketertiban dan perlindungan terhadap hak asasi manusia dan kedaulatan negara serta transparansi didalam setiap tindakan, menjunjung tinggi kebenaran, kejujuran, keadilan, kepastian hukum dan manfaat sebagai wujud pertanggungjawaban terhadap masyarakat, bangsa dan Negara. (Konstitusi RDTL 2001). Berkaitannya dengan fenomena yang ada, maka penelitian ini dilakukan pada Unidade Patrulhamentu Fronteira (UPF) Mota'ain - Batugade untuk mengetahui bagaimana pengaruh dukungan organisasional terhadap kepuasan kerja dan motivasi kerja anggota UPF didalam menjalankan misi khususnya sesuai dengan Lei Organika PNTL Pasal 33 No.9./2009; Sebagaimana anggota UPF merupakan tenaga profesional yang berhadapan langsung dengan kenyataan yang ada di lapangan, sementara masih ada banyak kendala yang di hadapi serta penanganan perbatasan yang belum optimal karena sesuai dengan kenyataannya di lapangan masih terlihat banyak kasus pelanggaran yang terjadi di perbatasan seperti maraknya aktifitas Illegal Crossing dan Illegal Business di sepanjang perbatasan yang tentunya membutuhkan solusi dari Organisasi Kepolisian Nasional Timor Leste itu sendiri.

Reformasi sektor keamanan yang terjadi setelah krisi tahun 2006 yang selama ini sedang berjalan cenderung mengabaikan Reformasi Manajemen Perbatasan Negara, Kawasan Perbatasan selama ini di anggap hanya sebagai Garis Perbatasan Negara dari prespektif Pertahanan sehingga paradigma keamanan mendominasi pengelolaannya, padahal aspek keamanan itu sendiri tidak semata-mata membicarakan aspek keamanan secara sempit yang melibatkan ancaman konvensional seperti invasi militer dari negara lain namun secara lebih kompleks, yakni keamanan manusia secara nasional yang meliputi aspek sosial, ekonomi bahkan politik perlu terus di benahi agar citra positif dapat terwujud dan pembenahan ini harus dilakukan secara internal disertai dengan kontrol dari luar seperti yang telah berlangsung selama ini.

Ada beberapa permasalahan yang terjadi pada Unidade Patrulhamentu Fronteira 
seperti kurangnya dukungan organisasi yang memadai berupa sumber daya manusia, sarana dan prasara kerja, kurangnya motivasi organisasi terhadap anggota, kurangnnya penghargaan terhadap prestasi anggota sehingga berakibat terhadap penurunan kinerja anggota untuk menjalankan fungsi dan tanggungjawabnya di dalam pengontrolan terhadap perbatasan darat Mota' ain - Batugade dan jika hal ini tidak diperhatikan secara dini maka kedepannya akan memberi peluan bagi pihak-pihak tertentu untuk melakukan aktivitas-aktivitas Illegal Crossing dan Illegal Business di sepanjang perbatasan seperti yang terjadi selama ini, yang kemungkinan besar kedepannya akan membawa dampak yang begitu serius terhadap kedaulatan bangsa dan negara seperti Illegal logging, Terorisme, Penyelundupan Narkotik, Human Trafficking,Trans Nasional Crime dan Crime Organized melalui perbatasan darat Mota'ainBatugade.

\section{Rumusan Masalah dan Tujuan Penelitian}

Berdasarkan uraian pada latar belakang yang telah dipaparkan diatas, maka masalah yang diteliti pada (UPF) dapat dirumuskan sebagai berikut.

1. Bagaimana pengaruh dukungan organisasi terhadap kepuasan kerja pada anggota Unidade Patrulhamentu Fronteira $(U P F)$ ?

2. Bagaimana pengaruh dukungan organisasi terhadap Motivasi kerja pada Anggota Unidade Patrulhamentu Fronteira $(U P F)$ ?

3. Bagaimana pengaruh Kepuasan Kerja terhadap Motivasi Kerja pada Anggota Unidade Patrulhamentu Fronteira - UPF?

\section{Tujuan Penelitian}

Berdasarkan masalah pada Anggota Unidade Patrulhamentu Fronteira - (UPF) yang telah dirumuskan dapat disusun tujuan penelitian sebagai berikut.

1. Menganalisis pengaruh dukungan organisasi terhadap kepuasan kerja pada Anggota Unidade Patrulhamentu Fronteira(UPF).
2. Menganalisis pengaruh dukungan organisasi terhadap Motivasi Kerja pada Anggota Unidade Patrulhamentu Fronteira(UPF).

3. Menganalisis pengaruh Kepuasan Kerja Terhadap Motivasi kerja pada Anggota Unidade Patrulhamentu Fronteira - (UPF).

Hasil penelitian ini diharapkan dapat memberikan manfaat sebagai berikut:

Manfaat Teoritis; Hasil penelitian ini diharapkan dapat dijadikan sebagai acuan bagi peneliti berikutnya yang berminat untuk mengkaji lebih mendalam terkait dengan masalah dukungan organisasi, kepuasan kerja dan motivasi kerja anggota Unidade Patrulhamentu Fronteira dalam penanganan masalah perbatasan darat Mota'ain-Batugade. Disamping itu, temuan penelitian ini juga diharapkan dapat menjadi tambahan informasi bagi pengembangan teori-teori yang terkait dengan variable yang digunakan dalam penelitian ini.

Manfaat Praktis; Hasil penelitian ini diharapkan dapat dijadikan acuan dan bahan pertimbangan dalam menetapkan berbagai kebijakan pengelolaan sumber daya manusia pada Polícia Nacional de Timor-Leste (PNTL) sehingga mampu meningkatan pelayanan kepada masyarakat Timor Leste yang membutuhkannya.

\section{Hipotesis Penelitian}

Gronroos, (1990), menemukan bahwa dukungan organisasi dan manajemen akanmeningkatkan motivasi perilaku orientasi pelanggan dari para pekerjanya. Moenir (1992: 119) mengemukakan bahwa sarana adalah segala jenis peralatan perlengkapan kerja dan fasilitas yang berfungsi sebagai alat utama/ pembantu dalam pelaksanaan pekerjaan, dan juga dalam rangka kepentingan yang sedang berhubungan dengan organisasi kerja. Sementara Locke (1976), dan Scheineder (1998), mengemukakan bahwa individu tertarik dan merasa nyaman berada di organisasi di karenakan adanya kesamaan karakteristik. Meglino, (1989), mengemukakan bahwa individu yang mempunyai nilai-nilai yang sama dengan organisasi, maka mereka akan 
mudah berinteraksi secara efisien dengan system nilai organisasi. Selain itu dukungan juga memunculkan semangat para timpekerja sehingga mereka dapat saling mempercayai dan saling membantu serta adanya hubungan baik antar pekerja di dalam lingkungan kerja (Shaametal, 1999).

Flippo (2000), faktor-faktor yang mempengaruhi kinerja karyawan adalah motivasi kerja, kepuasankerja, gaya kepemimpinan, iklim kerja, dukungan organisasi, disiplin kerja, motivasi kerja dan kemampuan karyawan. (Eisenberger, et all. 1986). dan (Allen, 1995;). Mengemukakan bahwa dukungan organisasi adalah bagaimana perusahaan menghargai kontribusi karyawan terhadap kemajuan perusahaan dan perhatian perusahaan terhadap kehidupan mereka. Hutchinson (1997), dan Kraimer (2001). Dukungan organisasi bisa juga dipandang sebagai komitmen organisasi pada individu yang di berikan dalam berbagai bentuk ekstrinsik atau material dan Intrinsik atau non material, berupa rewards, kompensasi yang setara, dan iklim organisasi yang adil, yang dilakukannya merupakan suatu investasi (Cropanzano et all., 1997). Mereka akan memberikan waktu, tenaga, dan usaha untuk memperolehapayang merekainginkan (Randal et all., 1999). Dalam hubungan tersebut, karyawan mempertimbangkan organisasi secara keseluruhan, bukan individual, dengan siapa mereka memiliki hubungan pertukaran (Wayne, et all.,1997) demi tercapainya tujuan organisasi.

Berdasarkan kajian konsep dan hasil-hasil penelitian sebelumnya yang telah diuraikan di atas maka dapat dirumuskan hipotesis penelitian:

1) H1: yaitu dukungan organisasional berpengaruh positif dan signifikan terhadap kepuasan kerja, terbukti. Hasil ini memberi petunjuk bahwa semakin baik dukungan organisasional yang dirasakan anggota (UPF) maka kepuasan kerja juga semaikan baik (semakin puas).

2) H2: yaitu dukungan organisasional berpengaruh positip dan signifikan terhadap motivasi kerja, terbukti. Hasil ini mengindikasikan bahwa, semakin baik dukungan organisasional yang dirasakan anggota Unidade Patrulhamentu Fronteira, maka motivasi kerja juga semakin baik (semakin tinggi).

3) H3: yaitu kepuasan kerja berpengaruh positip dan signifikan terhadap motivasi kerja, terbukti. Berdasarkan hasil pengujian inimaka dapat dinyatakan bahwa semakin baik kepuasan kerja anggota (UPF) (semakin puas) maka semakin baik (semakin tinggi) pula motivasi kerjanya kinerja anggota Unidade Patrulhamentu Fronteira (UPF) Mota'ain Batugade.

Rancangan Penelitian; adalah suatu rencana kerja terstruktur mengenai hubungan-hubungan antar variabel yang disusun sedemikian rupa sehingga hasil penelitian mampu menjawab setiap pertanyaan yang diajukan. Penelitian ini menggunakan desain Causal Explanatory untuk mengetahui hubungan antara variabel Dukungan Organisasi dengan Kepuasan Kerja, Dukungan Organisasi dengan Motivasi Kerja dan Kepuasan Kerja dengan Motivasi Kerja anggota Unidade Patrulhamentu Fronteira $U P F$ di perbatasan Mota'ain-Batugade.

Penelitian dilaksanakan di Kantor Komando UPF Batugade. Penelitian ini bertujuan untuk menganalisis pengaruh dukungan organisasi terhadap kepuasan kerja, Pengaruh Dukungan Organisasi terhadap Motivasi Kerja dan Pengaruh Kepuasan Kerja terhadap Motivasi Kerja anggota UPF di Perbatasan Mota'ain -Batugade.

Jenis data yang digunakan dalam penelitian ini, yaitu:

a) Data Kuantitatif, dalam penelitian ini adalah data jumlah anggota yang puas dan bermotivasi dengan dukungan organisasi Polisi Nasional de Timor Leste.

b) Data Kualitatif, Dalam penelitian ini yang termasuk dalam data kualitatif adalah lokasi penelitian, gambaran umum organisasi, karakteristik responden yang meliputi Nama, jenis kelamin, status, departemen, dan masa kerja.

Data pada penelitian ini bersumber dari data primer yang diambil secara langsung 
dari sumber data, dan data sekunder (diperoleh secara tidak langsung).

a) Sumber Primer; Merupakan data yang diperoleh secara langsung dari sumber data, diamati dan dicatat untuk pertama kalinya. Adapun data primer pada penelitian ini adalah data yang dikumpulkan melalui penyebaran kuesioner kepada anggota (UPF) di Pos Komando Unidade Patrulhamentu Fronteira Batugade yang telah dibuat dan disusun dalam bentuk rangkaian pertanyaan.

b) Sumber Sekunder; Data yang diperoleh peneliti secara tidak langsung melalui perantara (diperoleh dan dicatat oleh pihak lain). Adapun data sekunder yang digunakan dalam penelitian ini adalah data mengenai beberapa literatur maupun informasi yang menunjang lainnya seperti data dokumen Polisi Nasional Timor Leste yang diperlukan dalam penelitian ini, data tentang profil PNTL dan (UPF) itu sendiri, struktur Komando $(U P F)$, data tentang Dukungan Organisasi, Kepuasan dan Motivasi Kerja Anggota serta data lainnya yang terkait dengan penelitian ini.

Populasi dalam penelitian ini adalah keseluruhan anggota Unidade Patrulhamentu Fronteira yang terdiri dari 327 orang. Teknik pengambilan sampel yang digunakan adalah simple random sampling, karena populasi dianggap mempunyai probability yang sama untuk menjadi sampel. Untuk menentukan sampel dari populasi digunakan ketentuan sampel minimal $6 x$ jumlah indikator penelitian. Karena indikator penelitian adalah 10 maka sampel minimal yang akan diambil adalah 10 x 6 sampel yaitu 60 sampel (responden). Pada penelitian ini sampel yang akan di fokuskan adalah hanya pada Kepangkatan khususnya Ajente, Ajente Prinsipal, Ajente Xefe dan Serjentu sedangkan untuk Komandan hanya akan di lakukan wawancara untuk memperoleh data yang lebih akurat dan lengkap untuk penjelasan lebih lanjut dari kuisioner yang telah diperoleh dari anggota sampel dengan maksud untuk menggeneralisasikan hasil penelitian dan mengangkat kesimpulan penelitian sebagai suatu yang berlaku bagi populasi.

Instrumen

pengumpulan menggunakan metode kuesioner yaitu dengan memberikan daftar pertanyaan atau kuesioner secara langsung kepada para responden. Kuesioner tersebut merupakan angket tertutup yang terdiri dari dua bagian, yaitu bagian pertama yang terdiri atas item-item pertanyaan untuk mengetahui data pribadi responden dan bagian kedua untuk mendapatkan data mengenai dimensi dari konstruk yang dikembangkan dalam penelitian ini.Interval penelitian yang digunakan untuk memberi skor pada jawaban responden atas item-item pertanyaan dalam kuesioner mengadopsi skala likert. Variasi skor dengan sekala tersebut adalah: (5) sangat setuju, (4) setuju, (3) cukup setuju, (2) tidak setuju, (1) sangat tidak setuju. Skor yang diperoleh selanjutnya dicari ratarata skor per responden untuk didistribusikan berdasarkan kriteria tertentu sehingga dapat diprediksikan distribusi jawabannya.

Uji validitas digunakan untuk mengetahui valid tidaknya suatu instrumen pengukuran. Validitas adalah taraf sejauh mana alat ukur mampu mengukur apa yang seharusnya diukur. Prinsip validitas mengandung dua unsur yang tidak dapat dipisahkan yaitu kecermatan dan ketelitian. Suatu alat ukur yang valid tidak sekedar mampu mengungkapkan data dengan tepat akan tetapi juga harus memberikan gambaran yang cermat mengenai data tersebut. Valid tidaknya suatu instrumen dapat diihat dari nilai koefisien korelasi antara skor item dengan skor totalnya. Tinggi rendahnya validitas instrumen menunjukkan sejauh mana data terkumpul tidak menyimpang dari gambaran tentang variabel yang dimaksud. Uji validitas instrumen dalam penelitian ini menggunakan product momment correlation dengan cut off $\geq 0,30$ (Hair et al. 2006). Dari hasil pengolahan data uji validitas instrumen, terbukti bahwa instrumen penelitian dapat dinyatakan valid karena seluruh butir pertanyaan dalam instrumen untuk semua variabel memiliki koefisien korelasi positip dengan nilai koefisien korelasi di atas 0,30 ( $\mathrm{r}$ $>0,30$ ). Hal tersebut dapat disimpulkan bahwa instrumen yang digunakan telah memenuhi kriteria validitas. 
Tabel 5.4.

Deskripsi Variabel Dukungan Organizasional (X)

\begin{tabular}{|c|c|c|c|c|c|c|c|c|c|}
\hline \multicolumn{2}{|r|}{ Indikator } & \multicolumn{5}{|c|}{$\begin{array}{c}\text { Frekuensi Jawaban } \\
\text { Responden }\end{array}$} & \multirow{2}{*}{$\begin{array}{c}\text { Jumlah } \\
\text { Skor }\end{array}$} & \multirow[t]{2}{*}{$\begin{array}{l}\text { Rata- } \\
\text { Rata }\end{array}$} & \multirow[t]{2}{*}{ Keterangan } \\
\hline Kode & Label & 1 & 2 & 3 & 4 & 5 & & & \\
\hline $\mathrm{x} 1.11$ & $\begin{array}{l}\text { Organisasi menghargai } \\
\text { kontribusi saya }\end{array}$ & 0 & 0 & 18 & 41 & 1 & 223 & 3.72 & baik \\
\hline $\mathrm{x} 1.12$ & $\begin{array}{l}\text { Bantuan tersedia dari } \\
\text { organisasi }\end{array}$ & 0 & 39 & 13 & 8 & 0 & 149 & 2.48 & buruk \\
\hline $\mathrm{x} 1.13$ & $\begin{array}{l}\text { Organisasi sungguh- } \\
\text { sungguh peduli }\end{array}$ & 0 & 21 & 27 & 12 & 0 & 171 & 2.85 & cukup baik \\
\hline $\mathrm{x} 1.14$ & $\begin{array}{l}\text { Organisasi mau } \\
\text { membantu ketika } \\
\text { memerlukan bantuan }\end{array}$ & 0 & 12 & 43 & 5 & 0 & 173 & 2.88 & cukup baik \\
\hline $\mathrm{x} 1.1$ & Dukungan Organizasional & & & & & & & 2.98 & cukup baik \\
\hline $\mathrm{x} 1.21$ & $\begin{array}{l}\text { Rekan kerja peduli } \\
\text { dengan masalah saya }\end{array}$ & 0 & 0 & 13 & 47 & 0 & 227 & 3.78 & baik \\
\hline $\mathrm{x} 1.22$ & $\begin{array}{l}\text { Rekan kerja sangat } \\
\text { menolong menyelesaikan } \\
\text { tugas }\end{array}$ & 0 & 0 & 10 & 43 & 7 & 237 & 3.95 & baik \\
\hline $\mathrm{x} 1.23$ & $\begin{array}{l}\text { Rekan kerja mau } \\
\text { mendengarkan masalah } \\
\text { pekerjaan }\end{array}$ & 0 & 0 & 10 & 41 & 9 & 239 & 3.98 & baik \\
\hline $\mathrm{x} 1.24$ & $\begin{array}{l}\text { Rekan kerja suka } \\
\text { membantu }\end{array}$ & 0 & 0 & 27 & 27 & 6 & 219 & 3.65 & baik \\
\hline $\mathrm{x} 1.25$ & $\begin{array}{l}\text { UPF sungguh peduli } \\
\text { terhadap kesejahteraan } \\
\text { saya. }\end{array}$ & 0 & 0 & 53 & 7 & 0 & 187 & 3.12 & cukup baik \\
\hline $\mathrm{x} 1.26$ & UPF mau membantu & 0 & 11 & 39 & 10 & 0 & 179 & 2.98 & cukup baik \\
\hline $\mathrm{x} 1.27$ & $\begin{array}{l}\text { UPF menyiapkan sumber } \\
\text { daya }\end{array}$ & 0 & 21 & 30 & 9 & 0 & 168 & 2.80 & cukup baik \\
\hline x 1.2 & Dukungan Rekan Kerja & & & & & & & 3.47 & baik \\
\hline $\mathrm{x} 1.31$ & Atasan dapat di andalkan & 0 & 0 & 11 & 42 & 7 & 236 & 3.93 & baik \\
\hline
\end{tabular}

Uji reliabilitas merupakan uji kehandalan yang bertujuan untuk mengetahui seberapa jauh suatu alat ukur dapat diandalkan atau dipercaya. Uji reliabilitas menunjukkan sejauh mana suatu alat ukur dapat memberikan hasil yang relatif sama apabila dilakukan pengukuran kembali pada obyek yang sama. Untuk pengujian reliabilitas instrumen digunakan reliabilitas konsistensi internal, yaitu dengan menghitung Alpha Cronbach. Instrumen penelitian tergolong reliabel jika memiliki nilai Alpha Cronbach lebih besar atau sama dengan $0,60(\alpha \geq 0,60)$. Dari hasil pengolahan data uji reliabilitas instrumen, terbukti bahwa instrumen dapat dikatakan reliabel karena nillai Alpha Cronbach masingmasing variabel lebih besar dari $0,60(\alpha>$ $0,60)$. Hal tersebut dapat disimpulkan bahwa instrumen yang digunakan telah memenuhi kriteria reliabilitas.

Cara pengumpulan data yang digunakan dalam penelitian ini adalah:

1) Kuisioner, teknik pengumpulan data yang dilakukan dengan cara memberikan sejumlah pertanyaan tertulis secara terstruktur kepada responden penelitian berkaitan dengan 
Tabel 5.5.

Deskripsi Variabel Kepuasan Kerja (Y1)

\begin{tabular}{|c|c|c|c|c|c|c|c|c|c|}
\hline \multicolumn{2}{|r|}{ Indikator } & \multicolumn{5}{|c|}{$\begin{array}{c}\text { Frekuensi Jawaban } \\
\text { Responden }\end{array}$} & \multirow{2}{*}{$\begin{array}{c}\text { Jumlah } \\
\text { Skor }\end{array}$} & \multirow[t]{2}{*}{$\begin{array}{l}\text { Rata- } \\
\text { Rata }\end{array}$} & \multirow[t]{2}{*}{ Keterangan } \\
\hline Kode & Label & 1 & 2 & 3 & 4 & 5 & & & \\
\hline $\mathrm{y} 1.11$ & $\begin{array}{l}\text { Pekerjaan saya sangat } \\
\text { menarik. }\end{array}$ & 0 & 20 & 24 & 16 & 0 & 176 & 2.93 & cukup baik \\
\hline $\mathrm{y} 1.12$ & $\begin{array}{l}\text { Senang dengan kesempatan } \\
\text { belajar hal-hal baru }\end{array}$ & 0 & 27 & 16 & 17 & 0 & 170 & 2.83 & cukup baik \\
\hline y1.13 & $\begin{array}{l}\text { Pekerjaan sesuai dengan } \\
\text { tingkat tanggungjawab }\end{array}$ & 0 & 27 & 17 & 12 & 4 & 173 & 2.88 & cukup baik \\
\hline $\mathrm{y} 1.14$ & $\begin{array}{l}\text { Puas dengan pekerjaan } \\
\text { karenamembuat kemajuan }\end{array}$ & 0 & 17 & 28 & 13 & 2 & 180 & 3.00 & cukup baik \\
\hline y1.1 & Pekerjaan itu sendiri & & & & & & & 2.91 & cukup baik \\
\hline y1.21 & $\begin{array}{l}\text { Puas dengan gaji yang saya } \\
\text { terima }\end{array}$ & 0 & 29 & 24 & 7 & 0 & 158 & 2.63 & cukup baik \\
\hline $\mathrm{y} 1.22$ & $\begin{array}{l}\text { Puas dengan tunjangan } \\
\text { yang diberikan }\end{array}$ & 0 & 32 & 20 & 8 & 0 & 156 & 2.60 & buruk \\
\hline $\mathrm{y} 1.23$ & $\begin{array}{l}\text { Usaha tidak diberikan } \\
\text { imbalan yang seharusnya. }\end{array}$ & 0 & 35 & 15 & 10 & 0 & 155 & 2.58 & buruk \\
\hline y1.2 & Gaji & 0 & 29 & 15 & 7 & 0 & 131 & 2.61 & buruk \\
\hline y1.31 & $\begin{array}{l}\text { Puas dengan dasar yang } \\
\text { digunakan untuk promosi }\end{array}$ & 0 & 41 & 10 & 9 & 0 & 148 & 2.47 & buruk \\
\hline y1.32 & $\begin{array}{l}\text { Puas dengan kesempatan } \\
\text { untuk memperoleh promosi }\end{array}$ & 0 & 31 & 17 & 12 & 0 & 161 & 2.68 & cukup baik \\
\hline y1.33 & $\begin{array}{l}\text { Puas dengan kesempatan } \\
\text { memperoleh promosi gaji. }\end{array}$ & 0 & 31 & 17 & 12 & 0 & 161 & 2.68 & cukup baik \\
\hline y1.34 & Promosi jarang terjadi & 0 & 0 & 7 & 13 & 40 & 273 & 4.55 & sangat baik \\
\hline y1.3 & Kesempatan Promosi Karir. & & & & & & & 2.85 & cukup baik \\
\hline y1.41 & $\begin{array}{l}\text { Atasan selalu memberikan } \\
\text { dukungan. }\end{array}$ & 0 & 0 & 36 & 14 & 10 & 214 & 3.57 & baik \\
\hline $\mathrm{y} 1.42$ & $\begin{array}{l}\text { Atasan memiliki motivasi } \\
\text { yang tinggi. }\end{array}$ & 0 & 0 & 32 & 22 & 6 & 214 & 3.57 & baik \\
\hline y1.43 & $\begin{array}{l}\text { Atasan memberikan } \\
\text { kebebasan dalam } \\
\text { mengambil keputusan }\end{array}$ & 0 & 0 & 25 & 21 & 14 & 229 & 3.82 & baik \\
\hline y1.44 & $\begin{array}{l}\text { Atasan selalu bersikap jujur } \\
\text { terhadap anggotanya. }\end{array}$ & 0 & 0 & 0 & 48 & 12 & 252 & 4.20 & baik \\
\hline y1.4 & Pengawasan/ Supervisi & & & & & & & 3.79 & baik \\
\hline y1.51 & $\begin{array}{l}\text { Saya puas dengan tim kerja } \\
\text { saya. }\end{array}$ & 0 & 0 & 48 & 12 & 0 & 192 & 3.20 & cukup baik \\
\hline y1.52 & $\begin{array}{l}\text { Saya menikmati bekerja } \\
\text { dengan teman-teman. }\end{array}$ & 0 & 0 & 42 & 18 & 0 & 198 & 3.30 & cukup baik \\
\hline y1.53 & $\begin{array}{l}\text { Teman-teman kerja saya } \\
\text { sangat kooperatif. }\end{array}$ & 0 & 0 & 39 & 21 & 0 & 201 & 3.35 & cukup baik \\
\hline
\end{tabular}




\begin{tabular}{llllllllll}
\hline y1.54 & $\begin{array}{l}\text { Teman kerja selalu } \\
\text { memberikan dukungan. }\end{array}$ & 0 & 0 & 37 & 23 & 0 & 203 & 3.38 & cukup baik \\
y1.5 & Rekan Kerja & 0 & 0 & 39 & 21 & 0 & & 3.31 & cukup baik \\
Y1 & Kepuasan Kerja & 0 & 0 & 42 & 18 & 0 & & 3.09 & cukup baik \\
\hline
\end{tabular}

tanggapannya terhadap berbagai variabel yang diteliti dalam penelitian ini.

2) Wawancara, pengumpulan data dengan cara melakukan tanya jawab secara mendalam kepada responden penelitian untuk memperoleh data yang lebih akurat dan lengkap karena menyangkut penjelasan lebih lanjut dari kuisioner yang telah dibagikan tersebut.

3) Observasi adalah metode pengumpulan data melalui pengamatan langsung atau peninjauan secara cermat dan langsung di lapangan atau lokasi penelitian.

Variabel Penelitian; Berdasarkan pokok masalah dan hipotesis yang diajukan, variabel-variabel dalam analisis ini dapat diidentifikasi sebagai berikut:

1) Variabel eksogen (exogenous variable) yaitu variabel yang memiliki pengaruh terhadap variabel yang lain, namun tidak dipengaruhi oleh variabel lain dalam model. Atau dengan kata lain, variabel eksogen merupakan variabel yang hanya memiliki konsekuen saja. Yang menjadi variabel eksogen adalah Dukungan Organisasi (X).

2) Variabel endogen (endogenous variable) yaitu variabel yang memiliki pengaruh terhadap variabel lain dalam model. Atau dengan kata lain, suatu variabel yang memiliki anteseden dan atau konsekuen. Dalam penelitian ini yang menjadi variabel endogen adalah, Kepuasan Kerja (Y1), dan Motivasi Kerja (Y2).

\section{HASIL DAN PEMBAHASAN}

Berikut adalah penguraian variabel secara berurutan antara lain adalah Dukungan Organisasional (X), Kepuasan Kerja (Y1), dan Motivasi Kerja (Y2).

\section{1) Deskripsi Dukungan Organisasi (X)} Hasil analisis deskriptif Variabel Dukungan Organizasional (X) berupa frekuensi jawaban responden untuk setiap butir pertanyaan, jumlah skor dan nilai rata- rata skor setiap indikator serta nilai skor rata-rata keseluruhan untuk variabel.Variabel Dukungan Organisasi (X) dalam penelitian ini memili 3 (tiga) dimensi, dan masingmasing dimensi memiliki indikator-indikator tersendiri. Dimensi-dimensi tersebut adalah antara lain (X1.1); Dukunga Organisasional itu sendiri memiliki 3 indikator, (X1.2); Dukungan Rekan Kerja memiliki 7 indikator, dan (X1.3); Dukungan Supervisor/Komandan $(U P F)$ itu sendiri memiliki 4 indikator.

\section{2) Deskripsi Kepuasan Kerja (Y1)}

Variabel kepuasan kerja dalam penelitian ini memasukkan 5 (lima) dimensi, dan masing-masing dimensi memiliki indikator-indikator tersendiri. Dimensidimensi tersebut adalah antara lain (Y1.1); Pekerjaan itu sendiri memiliki 4 indikator, (Y1.2); Gaji yang di terima memiliki 3 indikator, (Y1.3); Kesempatan Promosi Karir memiliki 4 indikator, (Y1.4); Pengawasan/ Supervisi memiliki 4 indikator dan (Y1.5); Rekan Kerja memiliki 4 indikator.

\section{Deskripsi Motivasi Kerja (Y2)}

Variabelmotivasikerjadalampenelitian ini memasukkan 2 (dua) dimensi, dan masingmasing dimensi memiliki indikator-indikator tersendiri. Dimensi-dimensi tersebut adalah antara lain (Y2.1); Motivasi Kerja Intrinsik itu sendiri memiliki 6 indikator, (Y2.2); Motivasi Kerja Ekstrinsik yang memiliki 4 indikator. Hasil analisis deskriptifvariablemotivasi kerjaberupa frekuensi jawaban responden untuk setiap butir pertanyaan, jumlah skor dan nilai rata-rata skor setiap indikator serta nilai skor rata-rata keseluruhan untuk variabel.

\section{Analisis Partial Least Square (PLS)}

Penelitian ini menggunakan teknik analisis Partial Least Square (PLS) dengan Program SmartPLS. Tahapan dalam analisis Partial Least Square (PLS), terdiri dari: 1) 
Tabel 5.6.

Deskripsi Variabel Motivasi Kerja(Y2).

\begin{tabular}{|l|l|c|c|c|c|c|c|c|c|}
\hline \multicolumn{2}{|c|}{ Indikator } & \multicolumn{3}{|c|}{ Frekuensi Jawaban } & Jumlah & $\begin{array}{c}\text { Rata- } \\
\text { Rata }\end{array}$ & Keterangan \\
\hline Kode & \multicolumn{1}{|c}{ Label } & 1 & 2 & 3 & 4 & 5 & Skor & & \\
\hline y2.11 & $\begin{array}{l}\text { Sungguh peduli dengan } \\
\text { pekerjaan }\end{array}$ & 0 & 0 & 13 & 46 & 1 & 228 & 3.80 & baik \\
\hline y2.12 & $\begin{array}{l}\text { Pekerjaan memberi } \\
\text { kesempatan menunjukkan } \\
\text { prestasi kerja. }\end{array}$ & 0 & 31 & 20 & 9 & 0 & 158 & 2.63 & cukup baik \\
\hline y2.13 & $\begin{array}{l}\text { Pekerjaan saya san- } \\
\text { gat menyenangkan dan } \\
\text { menantang. }\end{array}$ & 0 & 35 & 15 & 9 & 1 & 156 & 2.60 & buruk \\
\hline y2.14 & $\begin{array}{l}\text { Pekerjaan saya } \\
\text { memberikan kesempatan } \\
\text { untuk belajar }\end{array}$ & 0 & 37 & 13 & 10 & 0 & 153 & 2.55 & Buruk \\
\hline y2.15 & $\begin{array}{l}\text { Mengambil pekerjaan ini } \\
\text { karena menantang dan } \\
\text { menyenangkan. }\end{array}$ & 0 & 23 & 29 & 7 & 1 & 166 & 2.77 & cukup baik \\
\hline y2.16 & $\begin{array}{l}\text { Pekerjaan saya memberi } \\
\text { kesempatan dalam } \\
\text { meningkatkan ketrampilan }\end{array}$ & 0 & 34 & 16 & 10 & 0 & 156 & 2.60 & buruk \\
\hline y2.1 & Motivasi Kerja (Intrinsik) & 0 & 23 & 27 & 9 & 1 & & 2.83 & cukup baik \\
\hline y2.21 & Motivasi uang & 0 & 0 & 12 & 17 & 31 & 259 & 4.32 & sangat baik \\
\hline y2.22 & $\begin{array}{l}\text { Menerima bayarang gaji } \\
\text { yang memuaskan }\end{array}$ & 0 & 36 & 13 & 10 & 1 & 156 & 2.60 & buruk \\
\hline y2.23 & $\begin{array}{l}\text { Melaksanakan pekerjaan } \\
\text { karena uang }\end{array}$ & 0 & 0 & 9 & 24 & 27 & 258 & 4.30 & sangat baik \\
\hline y2.24 & $\begin{array}{l}\text { Bersemangat karena } \\
\text { imbalan }\end{array}$ & 0 & 36 & 13 & 11 & 0 & 155 & 2.58 & buruk \\
\hline y2.2 & Motivasi Kerja(Ekstrinsik) & 0 & 0 & 32 & 18 & 10 & & 3.45 & baik \\
\hline Y2 & Motivasi Kerja & 0 & 12 & 25 & 23 & 0 & & 3.14 & cukup baik \\
\hline
\end{tabular}

evaluasi model pengukuran (outer model) untuk mengetahui validitas dan reliabilitas indikator-indikator yang mengukur variabel laten, dan 2) evaluasi model struktural (Inner Model) untuk mengetahui ketepatan model dan pengujian hipotesis.

\section{Evaluasi Model Pengukuran (Outer Model)}

Valuasi model pengukuran memeriksa validitas dan reliabilitas indikator-indikator yang mengukur konstruk atau variabel laten. Dalam penelitian ini ke tiga variabel laten, yaitu: dukungan organisasional (X), kepuasan kerja (Y1), dan motivasi kerja (Y2) merupakan model pengukuran yang bersifat reflektif, sehingga dalam evaluasi model pengukuran dilakukan pemeriksaan dengan convergent dan discriminant validity dari indikator, serta composite reliability untuk blok indikator.

1) Convergent validity;

Convergent validity bertujuan untuk mengukur validitas indikator sebagai pengukur konstruk yang dapat dilihat pada outer loading (output SmartPLS). Indikator dianggap valid jika memiliki nilai outer loading di atas 0.5 dan atau nilai T-Stastistic di atas 1.96. Selain itu juga, nilai outer loading dapat mengetahui 
Tabel 5.6.

Deskripsi Variabel Motivasi Kerja(Y2).

\begin{tabular}{lllll}
\hline Variabel & Indikator & $\begin{array}{l}\text { Outer } \\
\text { loading }\end{array}$ & T-Statistic & Keterangan \\
\hline Dukungan & $\mathbf{x 1 . 1}$ & $\mathbf{0 . 9 8 0 9}$ & 281.8494 & Signifikan \\
Organisasi & x1.2 & 0.9720 & 175.9977 & Signifikan \\
& x1.3 & 0.9569 & 122.3973 & Signifikan \\
Kepuasan Kerja & y1.1 & 0.9348 & 107.6694 & Signifikan \\
& y1.2 & 0.9684 & 146.2372 & Signifikan \\
& y1.3 & 0.9847 & 362.6220 & Signifikan \\
& $\mathbf{y 1 . 4}$ & $\mathbf{0 . 9 8 6 7}$ & 411.1520 & Signifikan \\
& y1.5 & 0.9542 & 91.3411 & Signifikan \\
Motivasi kerja & y2.1 & 0.9829 & 167.1288 & Signifikan \\
& $\mathbf{y 2 . 2}$ & $\mathbf{0 . 9 8 3 6}$ & 235.4765 & Signifikan \\
\hline
\end{tabular}

kontribusi setiap indikator terhadap variabel latennya. Outer loading indikator dengan nilai paling tinggi menunjukkan indikator tersebut sebagai pengukur terkuat atau paling penting dalam variabel latennya dapat dilihat pada tabel 4 berikut ini;

Berdasarkan informasi pada Tabel 4 .. maka dapat diketahui bahwa ketiga indikator pada variabel Dukungan Organisasional (X) memiliki nilai outer loading lebih besar dari 0.50 dan T-Statistic berada di atas 1,96. Dengan demikian dapat diartikan bahwa, indikatorindikator tersebut merupakan indikator yang valid sebagai pengukur variabel Dukungan Organisasional (X).Indikator Dukungan Organisasi (X1.1) merupakan ukuran terkuat dari variabel Dukungan organisasional (X), karena memiliki nilai outer loading paling besar (0.9809).

Hasil evaluasi variabel Kepuasan Kerja (Y1), juga nampak kelima indikator memiliki nilai outer loading lebih besar 0,50 dan T-Statistic di atas 1,96. Data ini membuktikan bahwa indikator Y1.1, Y1.2 Y1.3, Y1.4 danY1.5 merupakan indikator yang valid dalam merefleksikan variabel Kepuasan Kerja (Y1). Dalam kaitan ini ternyataKepuasan Kerja (Y1.4) merupakan indikator terkuat merefleksikan variabel Kepuasan kerja (Y1) dengan nilai outer loading sebesar 0.9867

Terakhir untuk hasil evaluasi variabel Motivasi kerja (Y2) ternyata juga kedua indikator memiliki nilai outer loading lebih besar dari
0,5 dan T-Statistik jauh di atas 1,96. Hal ini mengindikasikan bahwa Kepuasan Kerja (Y1.1) dan Motivasi Kerja (Y2.2) merupakan indikator yang valid sebagai pengukur Motivasi kerja, dengan nilai outer loading 0.9836 .

\section{2) Discriminant validity}

Dalam melakukan evaluasi

Discriminant validity dilihat perbandingkan nilai square root of average variance extracted (AVE) masing-masing variabel dengan korelasi antar variabel lainnya dalam model. Ketentuannya adalah apabila nilai square root of average variance extracted ( $\sqrt{ } A V E)$ variabellebih besar dari koefisien korelasi variabel lainnya menunjukkan bahwa indikator-indiaktor variable bersangkutan memiliki discriminant validity yang baik. Nilai AVE direkomendasikan lebih besar atau sama dengan 0,50 .Hasil evaluasi discriminant validity disajikan pada Tabel 5. Berikut ini.

Dengan mencermati informasi pada dalam Tabel 5 nampak bahwa ketiga variabel memiliki nilai AVE di atas 0,5 serta semua variabel memiliki nilai akar AVE lebih tinggi dengan koefisien korelasi antar variable.Hasil ini menunjukkan bahwa model memiliki discriminant validity yang baik.

3) Composite reliability

Evaluasi Composite reliability dimaksudkan untuk memeriksai nilai reliabilitas antara blok indikator dari variabel yang membentuknya. Composite reliability 
Tabel 5.

Pemeriksaan

Discriminant Validity

\begin{tabular}{lcclcc}
\hline Variabel & AVE & VAVE & $\begin{array}{l}\text { Dukungan } \\
\text { organisasional }\end{array}$ & $\begin{array}{l}\text { Korelasi } \\
\text { Kepuasan } \\
\text { kerja(Y1) }\end{array}$ & $\begin{array}{l}\text { Motivasi } \\
\text { kerja (Y2) }\end{array}$ \\
\hline Dukungan organisasional (X) & 0.9409 & 0.9700 & 1.000 & & \\
Kepuasan kerja(Y1) & 0.9331 & 0.9660 & 0.9428 & 1.000 & \\
Motivasi kerja (Y2) & 0.9668 & 0.9832 & 0.8984 & 0.9056 & 1.000 \\
\hline
\end{tabular}

Tabel 6.

Nilai Composite Reliability

\begin{tabular}{ll}
\hline Variabel & Composite reliability \\
\hline Dukungan organisasional (X) & 0.9795 \\
Kepuasan kerja(Y1) & 0.9859 \\
Motivasi kerja (Y2) & 0.9831 \\
\hline
\end{tabular}

Tabel 7.

Hasil Evaluasi Goodness of Fit

\begin{tabular}{lll}
\hline Model struktural & Variabel dependen & R-square \\
\hline 1 & Kepuasan kerja(Y1) & 0.8889 \\
2 & Motivasi kerja (Y2) & 0.8381 \\
\hline Perhitungan: Q2 $=1-[(1-\mathrm{R} 12)(1-\mathrm{R} 22)]$ \\
$=1-[(1-0.8889)(1-0.8381)]$ \\
Q2 $=1-[(0,1111)(0,1619)]=1-0,01799=0,98201$
\end{tabular}

dinyatakan baik kalau memiliki nilai di atas 0.70. Berdasarkan hasil pengolahan data dapat diketahui nilai composite reliability seperti ditunjukkan pada Tabel 6 . berikut ini.

Dengan memperhatikan data pada Tabel 6nampak bahwa nilai composite reliability ketiga variabel penelitian di atas 0,70 . Dengan demikian dapat diartikan bahwa blok indikator reliable mengukur variabel yang diteliti.

Dari hasil evaluasi keseluruhan yaitu convergent validity, discriminant validity, dan composite reliability sebagaimana diuraikan di atas, maka dapat disimpulkan bahwa indikator-indikator sebagai pengukur variabel merupakan pengukur yang valid dan reliabel.

\section{Evaluasi Model Struktural (Inner Model)}

Dalam evaluasi model structural (Inner Model) dilakukan dengan menghitung $\mathrm{Q}^{2}$ predictive relevance model, yang mengukur seberapa baik nilai observasi dihasilkan oleh model. $\mathrm{Q}^{2}$ dihitung berdasarkan pada nilai koefisien determinasi seluruh variabel dependen. Nilai $\mathrm{Q}^{2}$ berkisar dalam rentangan $0<\mathrm{Q}^{2}<1$ (satu). apabila model menghasilkan nilai semakin mendekati nilai 1 berarti model semakin baik. Dalam penelitian initerdapat dua variabel endogenus yaitu kepuasan kerja dan motivasi kerja. Nilai koefisien determinasi $\left(\mathrm{R}^{2}\right)$ keduanya disajikan pada Tabel 7.

Dari hasil perhitungan pada Tabel 7. diperoleh hasil evaluasi model struktural memiliki nilai $\mathrm{Q}^{2}$ sebesar 0,98201. Hasil ini mengindikasikan bahwa variabel dukungan organisasional dan kepuasan kerja memiliki tingkat prediksi yang baik terhadap Motivasi kerja. hasil ini juga dapat diartikan bahwa model struktural memiliki kesesuaian (goodness of fit model) yang baik. Hasil ini menunjukkan bahwa informasi yang terkandung dalam data penelitian sebesar 98,20 \% dapat menjelaskan model, sementara sisanya $1,80 \%$ dijelaskan oleh variabel lain yang tidak diteliti dalam model. 
Tabel 8.

Hasil Pengujian Hipotesis

\begin{tabular}{|l|l|l|l|l|}
\hline No & \multicolumn{1}{|c|}{ Hubungan Variabel } & $\begin{array}{c}\text { Koefisien } \\
\text { Jalur }\end{array}$ & T-Statistic & Keterangan \\
\hline 1 & $\begin{array}{l}\text { Dukungan organisasional (X) -> } \\
\text { Kepuasan kerja(Y1) }\end{array}$ & 0.9428 & 105.5598 & Signifikan \\
\hline 2 & $\begin{array}{l}\text { Dukungan organisasional (X) -> } \\
\text { Motivasi kerja (Y2) }\end{array}$ & 0.4016 & 5.0853 & Signifikan \\
\hline 3 & $\begin{array}{l}\text { Kepuasan kerja (Y1) -> Motivasi kerja } \\
\text { (Y2) }\end{array}$ & 0.5269 & 5.6270 & Signifikan \\
\hline
\end{tabular}

\section{Hasil Pengujian Hipotesis}

Pengujian hipotesis dilakukan dengan t-test pada masing-masing jalur pengaruh langsung secara parsial.Dari hasil pengolahan data, pada Tabel 8 berikut ini disajikanrekapitulasi hasil pengujian hipotesis. Uji t

Uji t ini digunakan untuk membuktikan pengaruh yang signifikan antara variabel independen (Dukungan Organisasional terhadap variabel dependen yaitu kepuasan kerja dan motivasi kerja anggota Unidade Patrulhamentu Fronteira - (UPF), Pengujian hipotesis ini dilakukan dengan t-test pada masing-masing jalur pengaruh langsung secara parsial.Dari hasil pengolahan data, pada Tabel 8 berikut ini disajikanrekapitulasi hasil pengujian hipotesis.

\section{Gambar 5.4.}

Hasil Output Partial Least Square (PLS)

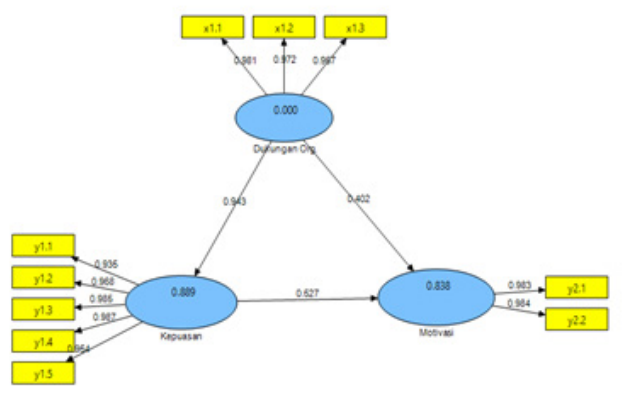

1. Dukungan Organisasional

(X) berpengaruh positif dan signifikan terhadap Kepuasan kerja $\left(\mathrm{Y}_{1}\right)$. Hasil ini ditunjukkan oleh koefisien jalur yang bernilai positif sebesar 0.9428 dengan T-Statistic = $105.5598 \quad$ (T-Statistic $>1,96)$. Dengan demikian hipotesis-1 $\left(\mathrm{H}_{1}\right)$, yaitu dukungan organisasional berpengaruh positif dan signifikan terhadap kepuasan kerja, terbukti. Hasil ini memberi petunjuk bahwa semakin baik dukungan organisasional yang dirasakan anggota (UPF) maka kepuasan kerja juga semaikan baik (semakin puas).

\section{Dukungan organisasional}

(X)

berpengaruh positip dan signifikan terhadap Motivasi kerja $\left(\mathrm{Y}_{2}\right)$. Hasil ini diindikasikandari koefisien jalur yang bernilai positip sebesar 0.4016 dengan $T$-Statistic $=5.0853$ ( T-Statistic $>$ 1.96). Dengan demikian maka hipotesis-2 (H2) yaitu dukungan organisasional berpengaruh positip dan signifikan terhadap motivasi kerja, terbukti. Hasil ini mengindikasikan bahwa, semakin baik dukungan organisasional yang dirasakan anggota Unidade Patrulhamentu Fronteira, maka motivasi kerja juga semakin baik (semakin tinggi).

3. Kepuasan kerja (Y1) berpengaruh positip dan signifikan terhadap Motivasi kerja (Y.2) . Hasil ini dibuktikan dari nilai koefisien jalur bernilai positip sebesar 0.5269 dengan T-Statistic $=5.6270$ (T-Statistic $>1,96)$. Hasil ini menunjukkan bahwa hipotesis-3 (H3), yaitu kepuasan kerja berpengaruh positip dan signifikan terhadap motivasi kerja, terbukti. Berdasarkan hasil pengujian inimaka dapat dinyatakan bahwa semakin baik kepuasan kerja anggota (UPF) (semakin puas) maka semakin baik (semakin tinggi) pula motivasi kerjanya kinerja anggota Unidade Patrulhamentu Fronteira (UPF) Mota'ain - Batugade.

\section{Pembahasan Hasil Penelitian}

\section{Pengaruh Dukungan Organisasaional}

Terhadap Kepuasan Kerja

Dukungan organisasional berpengaruh positif dan signifikan terhadap Kepuasan kerja $\left(\mathrm{Y}_{1}\right)$. Hasil ini ditunjukkan oleh koefisien jalur yang bernilai positif 
sebesar 0.9428 dengan T-Statistic $=105.5598$ (T-Statistic $>1,96)$ Dengan demikian hipotesis-1 $\left(\mathrm{H}_{1}\right)$, yaitu dukungan organisasional berpengaruh positif dan signifikan terhadap kepuasan kerja, terbukti hasil ini memberi petunjuk bahwa semakin baik dukungan organisasional yang dirasakan anggota (UPF) maka kepuasan kerja juga semaikan baik (semakin puas). Hasil penelitian ini sesuai dengan penelitian yang telah dilakukan oleh beberapa penelitian terdahulu yaitu: Pengaruh Dukungan Organisasional terhadap Kepuasan Kerja H1; Dukungan organisasi berpengaruh secara positif signifikan terhadap kepuasan kerja. Dari penelitian yang telah dilakukan dapat disimpulkan bahwa hipotesis yang menyatakan bahwa dukungan organisasional mempunyai pengaruh positif signifikan terhadap kepuasan kerja dapat diterima. Dengan demikian penelitian ini mendukung penelitian yang dilakukan oleh Yoon dan Lim (1999). dan Tatiyani (2004). Menyimpulkan hal yang sama bahwa dukungan organisasi mempunyai pengaruh positif terhadap kepuasan kerja. Flippo (2000), faktor-faktor yang mempengaruhi kinerja karyawan adalah motivasi kerja, kepuasankerja, gaya kepemimpinan, iklim kerja, dukungan organisasi, disiplin kerja, motivasi kerja dan kemampuan karyawan.

\section{Pengaruh Dukungan Organisasional Terhadap Motivasi Kerja.}

Dukungan organisasional

berpengaruh positip dan signifikan terhadap Motivasi kerja $\left(\mathrm{Y}_{2}\right)$. Hasil ini di indikasikan dari koefisien jalur yang bernilai positip sebesar 0.4016 dengan T-Statistic $=5.0853$ (T-Statistic > 1.96). Dengan demikian maka hipotesis-2 (H2) yaitu dukungan organisasional berpengaruh positip dan signifikan terhadap motivasi kerja, terbukti. Hasil ini mengindikasikan bahwa, semakin baik dukungan organisasional yang dirasakan anggota (UPF) maka akan semakin tinggi pula motivasi kerja anggta. Dari penelitian yang telah dilakukan dapat disimpulkan bahwa hipotesis yang menyatakan bahwa dukungan organisasional mempunyai pengaruh positif signifikan terhadap motivasi kerja dapat diterima. Dengan demikian penelitian ini mendukung penelitian yang dilakukan oleh Yoon dan Lim (1999). dan Tatiyani (2004). Menyimpulkan hal yang sama bahwa dukungan organisasi mempunyai pengaruh positif terhadap motivasi. Gibson (1996:198), mengemukakan keterkaitan kepuasan kerja dan motivasi. Sutrisno (2012), kepuasan kerja berhubungannya dengan produktivitas kerja dan pekerja dengan tingkat ketidakpuasan yang tinggi lebih mungkin untuk melakukan sabotase.

\section{Pengaruh Kepuasan Terhadap Motivasi Kerja.}

Kepuasan kerja $\left(\mathrm{Y}_{1}\right)$ berpengaruh positip dan signifikan terhadap Motivasi kerja (Y.2) . Hasil ini dibuktikan dari nilai koefisien jalur bernilai positip sebesar0.5269 dengan T-Statistic $=5.6270($ T-Statistic $>1,96)$. Hasil ini menunjukkan bahwa hipotesis-3 (H3), yaitu kepuasan kerja berpengaruh positip dan signifikan terhadap motivasi kerja, terbukti. Berdasarkan hasil pengujian inimaka dapat dinyatakan bahwa semakin baik kepuasan kerja anggota (UPF) (semakin puas) maka semakin baik (semakin tinggi) pula motivasi kerjanya. Dari penelitian yang telah dilakukan dapat disimpulkan bahwa hipotesis yang menyatakan kepuasan kerja berpengaruh positif terhadap motivasi kerja dapat diterima. Dengan demikian penelitian ini mendukung penelitian yang dilakukan oleh Parminto (1991), Ostroff (1992), Dyer dan Parker (1975), Harel dan Tzafrir (2001), Kirkman dan Shapiro (2001), Perry et al (2006) yang juga menunjukkan bahwa kepuasan kerja berpengaruh terhadap motivasi kerja karyawan. Robbins \& Judge (2011) mendefinisikan kepuasan kerja sebagai perasaan positif pada suatu pekerjaan.Motivasi sebagai pendorong dalam diri seseorang baik dari dalam (Intrinsik) maupun dari luar (ekstrinsik) seseorang untuk bertindak (Fuad Mas'ud, 2004). Mitchell, 1982:81 merumuskan motivasi mewakili proses-proses psikologikal, yang menyebabkan timbulnya, diarahkannya, dan terjadinya persistensi kegiatan kegiatan sukarela (volunter) yang 
diarahkan ke arah tujuan tertentu. Rumusan lain tentang motivasi diberikan oleh Stephen P Robbins dan Mary Coulter bahwa motivasi merupakan kesediaan untuk melaksanakan upaya tinggi untuk mencapai tujuan - tujuan keorganisasian.

\section{Implikasi Penelitian}

Implikasi penting penelitian ini adalah dibuktikannya dari beberapa hasil penelitian sebelumnya terkait dengan dukungan organisasi, kepuasan kerja dan motivasi kerja terhadap anggota Unidade Patrulhamentu Fronteira - (UPF). Hasil analisis menunjukkan bahwa persepsi anggota atas dukungan organisasi terhadap kepuasan kerja dan motivasi kerja anggota kebanyakan dipersepsikan buruk oleh anggota (UPF). Penelitian ini juga memberikan implikasi penting terkait dengan teori tentang dukungan organisasi, kepuasan kerja dan motivasi kerja. Hasil penelitian ini sangat mendukung penelitian-penelitian sebelumnya, terutama yang berkaitan dengan dukungan organisasi dengan kepuasan kerja, dukungan organisasi dengan motivasi kerja dan kepuasan kerja dengan motivasi kerja. Disisi lain, penelitian ini mampu membuktikan bahwa dukungan organisasional berperan secara langsun antara kepuasan kerja dan motivasi kerja karena semakin puas anggota dengan pekerjaannya, maka semakin meningkat pula motivasi kerjanya.

\section{SIMPULAN DAN SARAN}

Berikut adalah penjelasan kesimpulan dari hasil penelitian yang telah di lakukan mengenai Pengaruh Dukungan Organisasional Terhadap Kepuasan Kerja dan Motivasi Kerja Anggota Unidade Patrulhamentu Fronteira(UPF) antara lain adalah sebagai berikut; Dukungan Organisasional berpengaruh positif signifikan secara langsung terhadap Kepuasan kerja. Hal ini mengandung makna bahwa apabila meningkatnya dukungan organisasi maka akan dapat meningkatkan pulakepuasan kerja anggota. Dukungan Organisasi berpengaruh positif signifikan secara langsung terhadap Motivasi kerja.
Hal ini mengandung makna, bahwa apabila meningkatnya dukungan organisasi maka akan dapat meningkatkan pula motivasi kerja anggota. Kepuasan kerja berpengaruh positif signifikan secara langsun terhadap motivasi kerja. Hal ini mengandung makna, bahwa apabila meningkatnya kepuasan kerja maka akan dapat meningkat pula motivasi kerja anggota.

Berdasarkan hasil penelitian dan kesimpulan, berikut ini beberapa saran untuk meningkatkan dukungan organisasi terhadap kepuasan kerja dan motivasi kerja anggota Unidade Patrulhamentu Fronteira sebagai berikut: Organisasi menghargai kontribusi anggota dan mau membantu anggota ketika membutuhkan bantuan tetapi kurang menyediakan sarana dan prasarana bagi anggota ketika membutuhkan bantuan untuk menjalakan tugasnya dengan baik. Sementara rekan kerja dan atasan dapat diandalkan karena mau mendengarkan permasalahan yang dihadapi baik itu permasalahan pribadi maupun permasalahan tugas Unidade Patrulhamentu Fronteira. Pekerjaan itu sendiri cukup menarik bagi anggota untuk belajar halhal baru dan sesuai dengan tanggungjawabnya karena dapat membawa kemajuan pada (UPF) sendiri, tunjangan, imbalan, gaji dan dasar promosi karir perlu ditingkatkan tetapi untuk sementara cukup puas dengan dasar promosi yang ada, sementara atasan (UPF) sendiri perlu tetap mempertahankan dukungan terhadap anggota yang selama ini berjalan dengan baik seperti atasan selalu memberikan dukungan, motivasi yang tinggi, selalu jujur dan memberikan kebebasan bagi anggota didalam pengambilan keputusan dan mau mendengarkan permasalahan baik itu permasalahan kerja maupun permasalahan pribadi anggotanya serta pengawasan atasan terhadap anggota dan kooperatif tim kerja yang cukup begitu baik dari rekan kerja pun perlu di pertahankan. Mempertahankan kepedulian terhadap motivasi anggota dan memberikan kesempatan bagi anggota untuk menunjukan prestasi kerja dan kepedulian dengan pekerjaan ini dengan baik dan motivasi Intrinsiknya yang sangat baik sehingga membuat anggota 
tetap mengambil pekerjaan ini hanya bukan karena uang melainkan komitmen anggota terhadap organisasional khususnya Unidade Patrulhamentu Fronteira itu sendiri. Organisasi Kepolisian Nasional Timor Leste perlu menyediakan bantuan yang layak serta kepedulian terhadap permasalahan kerja, tunjangan, imbalan, gaji dan dasar promosi yang digunakan, kesempatan belajar hal baru bagi anggota (UPF) untuk meningkatkan keterampilan khusus yang dapat membantu anggota didalam penanganannya terhadap perbatasan darat Mota'ain - Batugade khususnya Timor Leste dengan RI. Apabila organisasi Kepolisian Nasional Timor Leste kurang memperhatika hal-hal tersebut diatas terhadap anggota Unidade Patrulhamentu Fronteira untuk memotong jalur keluar-masuk illegal maka kemungkinan besar kedepannya akan mumbawa dampak negatif terhadap halhal seperti; Meningkatnya ancaman kejahatan transnasional perkembangan organisasi kejahatan internasional yang didukung oleh perkembangan teknologi persenjataan, komunikasi dan informasi terhadap keamanan dalam negeri TL melalui implementasinya border pass dan diberlakukannya pasar bebas seperti yang terjadi selama ini sehingga akan meningkatnya mobilitas penduduk baik inter maupun antar negara seperti narkoba, penyelundupan, pencucian uang, Human Trafficking bahkan ancaman keselamatan, keamanan dan lalulintas nuklir. Kurangnya kepatuhan dan disiplin masyarakat terhadap hukum perbatasan dan perbedaan pemahaman terhadap keanekaragaman budaya, kondisi sosial, kesenjangan kesejahteraan, tingkat penganguran, tingkat kemiskinan penduduk yang merupakan faktor korelatif antara kriminolog dan tantangan bagi kepolisian Unidade Patrulhamentu Fronteira sehingga akan membukanya peluan besar bagi para para Illegal Business dan illegal crosser di sepanjang perbatasan darat Mota'ain Batugade.

\section{REFERENSI}

Anastasia Tania dan Eddy M. Sutanto Program Manajemen Bisnis 2013; Program
Studi Manajemen, Universitas Kristen Petra J1. Siwalankerto 121-131, Surabaya;

Pengaruh motivasi kerja dan kepuasan kerja terhadap komitmen organisasional karyawan PT. DAI KNIFE di Surabaya.

Arum Darmawati, Lina Nur Hidayati, \& Dyna Herlina S. Universitas Negeri Yogyakarta 2013 - Pengaruh Kepuasan Kerja dan Komitmen organisasi Terhadap Organizational Citizenship Behavior.

As'ad, M. 2004. Psikologi Industri. Yogyakarta: Liberty. Edisi Ke-empat.

As'ad, M. (2003). Psikologi Industri: Seri Sumber Daya Manusia. Yogyakarta: liberty.

Azeem, S.M. 2010. Job satisfaction and organizational commitment among employees in the Sultanate of Oman, Journal of Psychology, Vol.1, No. 4, pp. 295-299.

Bradley L.Kirkman dan Debra L.Shapiro, 2001, "The Impact of Cultural Values On Job Satisfaction and Organizational Commitment in Self-Managing Work Teams: The Mediating Role of Employee Resistance,"Academy of Managing Journal, Vol.44, No.3, p.557-569.

Bishop \& Chen (2003 : 4). (Cohen, Ledford \& Spreitzer, 1996). (Scott et al ,2003: 5). (cf. Eppard, 2004 ; 27). Keterkaitan lingkungan kerja, tradisi dan budaya lokal.

Church Allan H. et al, 1992, "Evolution or Revolution in the Values of Organization Development: Commentary on the State of the Field", Journal of Organizational Change Management, Vol. 5, No.4 P. 6-23. 
Cropanzano, R., James K., \& Konovsky, M.A, 1993, "Dispotional Effectivity as a Predictor of Work Attitude and Job Performance", Journal of Organizational Behavior, No.14, and p: 595-606.

Dessler, Gary, 1992, "Manajemen Sumber Daya Manusia", PT Prenhalindo, Jakarta.

Dekretu Lei Organika PNTL No. 8/2004 Tertanggal 5 Mei 2004. Pasal 33 Mengenai Terciptanya UPF dan Pospos Perbatasan. Dekrit Hukum Pemerintah atau Decree Law No. 8/May 2004.

Edwin B, Flippo, Manajemen Personalia, 1994, Jilid 1, Edisi Keenam, Jakarta: Erlangga Eisenberger, R., Huntington, R., Hutchison, S., \& Sowa, D. (1986). Perceived Organizational Support. Journal of Applied Psychology. 71, 500-507.

D. Wahyu Ariani (2010), Program Studi Fakultas Ekonomi - Universitas Atmajaya Yogyakarta. Jl. Babarsari, No. 43 Yogyakarta, 55281. Jurnal Keuangan dan Perbankan, Vol. 15, no 3. September 2011, hlm 416-427 terakreditasi SK. No.64a/DIKTI/Kep/2010

D. Wahyu Ariani 2010; Fakultas Ekonomi Universitas Atma Jaya YogyakartaBuletin Ekonomi Vol. 8, No. 1, April hal 1-70 9.

Fuad Mas'ud, 2004, Survai Diagnosis Organisasional (Konsep dan Aplikasi), Badan Penerbit Universitas Diponegoro.

Flippo, E.B., 1984, Personnel Management. Sixth Edition, McGraw-hill Book Co, Singapore.
First Group of UN2004 - Trained East Timor Police Officers for Taking up duties tertanggal 14 Mei.

Gibson, James L, John M Ivancevich dan James H Donely Jr, 1997, organisasi dan Manajemen: Perilaku, Struktur, Proses, Edisi 4, Terjemahan Djoerban Wahid, penerbit Erlangga, Jakarta.

Gronroos, c., 1990, Service Management and Marketing: Managing the Moment of Truth in Service Competition, Lexington, MA: Lexington Books.

Kirkman, Bradley L., 2001, "The Impact of Cultural Values on Job Satisfaction and Organizational Commitment in Self-Managing Work Teams: The Mediating Role of Employee Resistance", Academy of Management Journal, Vol.44 No.3 p. 557-569.

Konstitusi Republica Demokratica de Timor Leste; 2001. Pasal 147 ayat 1, 2 dan 3. Fungsi dan Peranan PNTL.

Laporan Komisi Internasional 2006 terhadap Krisis Internal Timor Leste yang terjadi di Kubuh F-FDTL.

Malthis. Robert. (2008). Human Resource Manajemen. Jakarta: Salemba empat

Maslow, A, 1987, Human Motivation, Cambridge University Press.

Mc. Clellan, D.C, 1987, Human Motivation, Cambridge University Press.

Mathis, Robert L dan Jackson, John H 2001, Manajemen Sumber Daya Manusia, Edisi pertama, Salemba Empat, Jakarta.

Mathiew \& Jones. (1991). Further Evidence For The Discriminant Validity Measures of Organizational Commitment, Job Satisfaction, and 
Job Involvement. Journal of Applied Psychology. Vol. 161.

Mas'ud, Fuad 2004, Survai Diagnosis Organisasional Konsep dan Aplikasi, Cetakan ke 4, Semarang: Badan Penerbit Undip

Mathis, Robert L dan John H Jackson, 2001. Manajemen Sumber Daya Manusia, Buku I. Jakarta: Salemba Empat.

Ostroff, Cheri, 1992. "The Relationship between Satisfaction, Attitudes and Performances: An Organizational Level Analysis", Journal of Applied Psychology, Vo. 77 No.6, P. 963-974.

Pernyataan Pers UNTAET Dili Timor Leste 2000, 12 Juli.

Peraturan UNTAET 2001/UNTAET, Dili Timor Leste 10 Agustus.

Penny Setyowati Nugraheny 2009; analisis pengaruh kepuasan kerja, dukungan organisasi, dan gaya kepemimpinan terhadap motivasi kerja dalam meningkatkan kinerja karyawan. (Studi Pada PT. Bank Mandiri (Persero) Tbk Kota Semarang).

PNTL Organic Law/Lei Organica PNTL No. 9/2009. Misi Khusus Unidade Patrulhamentu Fronteira - UPF.

Rahadyan Probo Tranggono dan Andi Kartika 2008; Pengaruh Komitmen Organisasional dan Profesional Terhadap Kepuasan Kerja Auditor dengan Motivasi sebagai variabel intervening (Studi Empiris pada Kantor Akuntan Publik di Semarang) Alumnus dan Dosen Fakultas Ekonomi Universitas Stikubank Semarang, Jurnal Bisnis dan Ekonomi
(JBE), Maret, Hal. 80 - 90 Vol. 15, No.1ISSN: 1412-3126.

Resolusi Dewan Keamanan Perserikatan Bangsa-Bangsa (PBB) UNSCR 1338 S/RES 1338 tertanggal 31 Januari 2001. UNSCR 1410, S/RES 1410 Tertanggal 17 Mei 2002, UNSCR Tertanggal 17 Mei 2002, UNSCR 1480, 19 Mei 2003, UNSCR 1473 S/RES 1473 Tertanggal 4 April 2003, 1599, S/RES/1599, Tertanggal 14 Mei 2004. Regulamentu Disiplinariu Polisia Nasional Timor Leste No. 8/2004, alínea 5.

Robbin, P. Stephen. 2001. Perilaku Organisasi. Konsep, Kontroversi, Aplikasi. Jilid I. Edisi Kedelapan. Jakarta: Prenhallindo.

Robbins, Stephen P; Judge, Timothy A. 2008. Perilaku Organisasi. Buku 1. Jakarta: Salemba Empat cetakan ke 11.

Rhoades, L dan Eisenberger, R. (2002). Perceived Organizational Support: A Review of the Literature. Journal of Applied Psychology, 87 (4): 698-714

Rhoades, L.; Eisenberger, R.; dan Armeli, S. (2001). Affective Commitment to Organization: The Contribution of Perceived Organizational Support. Journal of Applied Psychology, 86: $825-836$

Wayne, S. J., Shore, L. M., Bommer, W.H., \& Tetrick, L. E. (2002). The Role of Fair Treatment and Reward in Perceptions of Organizational Support and Leader-Member Exchange. Journal of Applied Psychology. 87, 590-598. 